\title{
SOSIALISASI GOOGLE CLASSROOM SEBAGAI MEDIA PEMBELAJARAN ONLINE AKIBAT DAMPAK PANDEMIC COVID 19 DI SMPIT AL-MUSTOFA
}

\author{
Achmad Udin Zailani ${ }^{1}$, Agung Perdananto ${ }^{2}$, Nurjaya $^{3}$ Sholihin $^{4}$, Samsoni $^{5}$ \\ 1,2,3,4,5 Dosen Teknik Informatika, Universitas Pamulang \\ Email: dosen00270@unpam.ac.id
}

\begin{abstract}
The Community Service Program which was carried out aimed to train students and teachers of SMPIT Al-Mustofa to use e-learning media Google Classroom during the Covid 19 pandemic. With this training, students and teachers can optimize the use of Google Classroom in the learning process. The implementation of this service consists of three stages, namely: preparation, implementation, and evaluation. The preparation stage was carried out to explore problems related to the potential for e-learning during the Covid 19 pandemic. At this stage, e-learning material was delivered and training on how to access and use Google Classroom. The evaluation phase is carried out to find out obstacles during training. This activity resulted in an increase in the knowledge of students and teachers of SMPIT Al-Mustofa about e-learning and skilled in using Google Classroom as an interactive and fun online learning medium in the process of teaching and learning activities during the Covid 19 pandemic and e-learning products, namely Google Classroom as an easy-to-use online learning medium.
\end{abstract}

Keywords: Google Classroom, Online Learning, Covid 19

\section{PENDAHULUAN}

Semenjak WHO menetapkan wabah pandemic Covid 19 sejak 11 Maret 2020 secara global. Setiap hari data korbanpun semakin bertambah hampir diseluruh dunia. Bahkan dalam situs UNESCO dikemukakan bahwa pandemi corona ini mengancam 577 juta pelajar di dunia. Di Indonesia, beberapa kampus dan sekolah mulai menerapkan kebijakan kegiatan belajar mengajar dari jarak jauh atau kuliah online. Pemerintah pusat dan daerah membuat aturan tentang mengambil jarak untuk memutus rantai penularan COVID-19. Tempat ibadah dan Mall pun mulai sepi, agenda massa yang sifatnya mengumpulkan khalayak ramai ditiadakan sehingga muncul istilah 'Work From Home' (WFH). Sekolah dan kampus dipaksa untuk melakukan kegiatan belajar dan mengajar secara daring. Selain itu, Covid-19 memberikan dampak serius di sektor pendidikan, baik di Indonesia maupun secara global. Pemerintah mengumumkan Ujian Nasional (UN) di tahun ini resmi ditiadakan. Mulai dari tingkat Sekolah Dasar (SD) hingga setingkat 
Sekolah Menengah Atas (SMA). Pemerintah telah meniadakan Ujian Nasional (UN) untuk tahun 2020.

Media pembelajaran online memiliki peran yang sangat singnifikan dalam menentukan kelancaran proses kegiatan belajar mengajar tanpa tatap muka secara langsung. Media pembelajaran dapat berupa teknologi yang memanfaatkan internet maupun aplikasi yang ada. Penerapan media pembelajaran sangat membantu keberhasilan dalam proses belajar mengajar (Soni, et al., 2018). Proses pembelajaran melalui media internet sudah sering dilakukan diberbagai institus. Terlebih dalam kondisi pandemic saat ini, maka media pembelajaran online menjadi alternative untuk tetap melaksanakan kegiatan belajar mengajar. Salah satu media yang digunakan yaitu Google drive yang berguna untuk berbagi dokumen. Penggunaan media pembelajaran bisa membangkitkan keinginan, minat baru, dapat memotivasi dan merangsang kegiatan belajar bahkan mempengarui psikologis peserta didik (Soni, et al., 2018), teknologi dan media bisa berperan banyak untuk belajar. Jika pengajarannya berpusat pada guru, teknologi dan media digunakan untuk mendukung penyajian pengajaran. Di sisi lain, apabila pengajaran berpusat pada peserta didik, para peserta didik merupakan pengguna utama teknologi dan media.

Banyak media online yang bisa digunakan untuk mengganti kegiatan belajar mengajar dikelas. Salah satunya menggunakan media Google Classroom. Pemanfaatan Google Classroom dapat dilakukan di Komputer, Laptop, Tab dan Handphone. Sehingga aplikasi ini dapat lebih mudah untuk diterapkan dan disesuaikan dengan kondisi yang ada. Kelebihan lain dari Google Clasroom yaitu emai user mengunakan gmail yang sudah terpaut sama OS Android dan terhubung dengan Google drive untuk media penyimpannnya. Oleh karena itu, penggunaan Google Classroom ini sesungguhnya mempermudah guru dalam mengelola pembelajaran dan menyampaikan informasi secara tepat dan akurat kepada peserta didik (Sabran \& Sabara, 2019).

Guru dalam melaksanakan kegiatan pembelajaran yang selama ini berlangsung cenderung menggunakan cara konvensional, guru lebih dominan dan hanya menggunakan metode ceramah yang disertai dengan menjawab pertanyaan-pertanyaan yang ada dibuku paket maupun LKS sehingga pembelajaran hanya berjalan satu arah yakni berpusat pada guru, dan kurang mengarah pada siswa, padahal dengan berlakunya kurikulum tingkat satuan pendidikan (KTSP) sekarang ini, pembelajaran 
diharapkan telah berpusat pada siswa untuk mencapai pembelajaran yang optimal. Keadaan dengan pembelajaran berpusat pada guru mengakibatkan siswa menjadi pasif dan guru sulit mengetahui apakah siswa sudah dapat memahami atau belum memahami dari materi yang telah disampaikan. Siswa yang pasif dan kurang aktivitas siswa pada saat proses pembelajaran menyebabkan pembelajaran menjadi tidak bermakna bagi siswa dan siswa sulit untuk memahami materi yang disampaikan guru.

Melalui pembelajaran dengan blended learning, maka peserta didik merasa nyaman dan aktif dalam mengkonstruksi pengetahuannya. Guru dapat memanfaatkan berbagai fitur yang terdapat pada Google Classroom seperti assignments, grading, communication, time-cost, archive course, mobile application, dan privacy. Google Classroom adalah aplikasi yang dibuat oleh google yang bertujuan untuk membantu guru dan peserta didik apabila kedua hal tersebut berhalangan, mengorganisasi kelas serta berkomunikasi dengan peserta didik tanpa harus terikat dengan jadwal matapelajaran di kelas. Penyampaian pembelajaran dengan e-learning merupakan pembelajaran dengan memanfaatkan teknologi internet untuk meningkatkan lingkungan belajar dengan konten yang kaya dengan cakupan yang luas. Elearning merupakan pemanfaatan media pembelajaran menggunakan internet, untuk mengirimkan serangkaian solusi yang dapat meningkatkan pengetahuan dan keterampilan. Setiap metode pembelajaran harus mengandung rumusan pengorganisasian bahan pelajaran, strategi penyampaian, dan pengelolaan kegiatan dengan memperhatikan faktor tujuan belajar, hambatan belajar, karakteristik peserta didik, agar dapat diperoleh efektivitas, efisiensi, dan daya tarik pembelajaran (Sabran \& Sabara, 2019).

Google Classroom mempunyai kelebihan diantaranya adalah pembuatan dan pemberian tugas bisa dilakukan penelesaiannya melewati google drive sambil menggunakan gmail untuk membuat pemberitahuan di ruang kelas google. Para murid dapat diundang se sebuah ruang kelas dengan beberapa cara yaitu melalui basis data lembaga, melalui sebuah kode pribadi yang kemudian dapat ditambahkan di dalam antarmuka murid atau dengan didatangkan secara sendirian dari sistem pengelolaan keterangan sekolah. Google classroom disatupadukan dengan gooflr calender dari para murid dan guru. Tiap-tiap kelas dibuatkan dengan adanya sebuah berkas yang dipisahkan oleh Google classroom dalam masing-masing layanan google dimana para murid dapat menyerahkan hasil kerjanya untuk digolong-golongkan oleh seorang guru (Hakim, 2016). 
Penyampaian kabar melalui gmail membebaskan para guru untuk membuat pengumuman serta menanyakan mengenai soal-soal kepada muridnya dalam kelasnya masing-masing. Sedangkan kelemahan Google classroom antara lain: hanya bisa diakses dengan akun google, sebenarnya sama dengan media social yang lain, mereka harus log in menggunakan akun yang dibuat di media social tersebut. Namun, di media social lain biasanya untuk sign in bisa memakai akun email dari platform manapun. Sehingga memungkinkan untuk menerima akses pengguna dari kalangan tak terbatas. Sedangkan Google Classroom hanya bisa diakses oleh pemilik akun google. Hal ini sebagai syarat mutlak untuk bisa menikmati fitur-fitur yang ada didalamnya. Sebenarnya sih wajar aja, karena memang Google Classroom ini milik google, tapi resikonya memang hanya bisa diakses oleh kalangan terbatas. Yaitu yang memiliki akun google, Tidak ada tombol share untuk berbagi kegiatan kelas dengan orang lain.

SMPIT Al Mustofa merupakan salah satu SMP Swasta dibawah Yayasan Pendidikan Islam Al Mustofa yang beralamat di Jl. MH. Thamrin Kebon Nanas Rt.03/01 Kota Tangerang yang mendapat dampak langsung dari pandemic covid-19. Dimana mengharuskan belajar jarak jauh selama pandemic tesebut. Pada pelatihan ini diterapkan pembelajaran dalam jaringan (daring) yang memanfaatkan salah satu aplikasi google kelas (classroom.google.com) dengan pendekatan model pembelajaran kolaboratif. Dengan menggunakan aplikasi ini guru dapat memeberikan materi secara daring sehingga siswa dapat mendapatkan materi dengan lebih mudah. Proses pemberian tugas dan kuis dapat juga dilakukan secara online akan mempermudah proses belajar mengajar. Siswa dapat memberikan pertanyaan langsung melalui komentar pada materi yang belum dipahami. Siswa lain juga dapat saling berinteraksi satu dengan lainnya, sehingga diskusi kelas bisa berjalan dengan baik.

\section{Rumusan Masalah}

"Bagaimana memberikan pelatihan Google Classroom untuk siswa/siswi dan para guru di SMPIT Al Mustopa akibat dampak pandemic Covid -19?

\section{Tujuan Penelitian}

Tujuan umum dari kegiatan pengabdian kepada masyarakat ini adalah mengenalkan siswa/siswi SMPIT Al-Mustofa dan para guru dalam mengenalkan Google 
Classroom sebagai media alternative pembelajaran online. Secara khusus tujuan kegiatan pengabdian kepada masyarakat ini adalah:

a. Mensosialisasikan Google Classroom kepada Siswa/Siswi dan para guru SMPIT Al-Mustofa; dan

b. Membantu menggunakan media Google Classroom sebagai alternative untuk kegiatan belajar online terutama disaat pandemic Covid 19.

Adapun manfaat dari pengabdian kepada masyarakat adalah mentransfer pengetahuan kepada peserta tentang Google Classroom untuk dijadikan sebagai media alternative pemebalajaran online/daring khususnya pada saat pandemic covid 19.

\section{TINJAUAN PUSTAKA}

Google Classroom merupakan sebuah aplikasi yang memungkinkan terciptanya ruang kelas di dunia maya. Selain itu, Google classroom bisa menjadi sarana distribusi tugas, submit tugas bahkan menilai tugas-tugas yang dikumpulkan (Hakim, 2016). Dengan demikian, aplikasi ini dapat membantu memudahkan Guru dan Murid dalam melaksanakan proses belajar dengan lebih mendalam. Hal ini disebabkan karena baik Murid maupun Guru dapat mengumpulkan tugas, mendistribusikan tugas, menilai tugas di rumah atau dimanapun tanpa terikat batas waktu atau jam pelajaran. Google classroom sesungguhnya dirancang untuk mempermudah interaksi Guru dan Murid dalam dunia maya. Aplikasi ini memberikan kesempatan kepada para Guru untuk mengeksplorasi gagasan keilmuan yang dimilikinya kepada Murid. Guru memliki keleluasaan waktu untuk membagikan kajian keilmuan dan memberikan tugas mandiri kepada Murid selain itu, Guru juga dapat membuka ruang diskusi bagi para Murid secara online. Namun demikian, terdapat syarat mutlak dalam mengaplikasikan google classroom yaitu membutuhkan akses internet yang mumpuni. Aplikasi google classroom dapat digunakan oleh siapa saja yang tergabung dengan kelas tersebut. Kelas tersebut adalah kelas yang didesain oleh Guru yang sesuai dengan kelas sesungguhnya atau kelas nyata di sekolah. Terkait dengan anggota kelas dalam google classroom (Novian, 2019). Google classroom menggunakan kelas tersedia bagi siapa saja yang memiliki Google Apps for Education, serangkaian alat produktivitas gratis termasuk gmail, dokumen, dan drive.Rancangan kelas yang mengaplikasikan google classroom sesungguhnya ramah lingkungan. Hal ini dikarenakan Murid tidak menggunakan kertas dalam mengumpulkan tugasnya. Hal ini 
sejalan dengan pendapat Herman dalam (Hammi, 2017) yang memaparkan bahwa dalam google classroom kelas dirancang untuk membantu Guru membuat dan mengumpulkan tugas tanpa kertas, termasuk fitur yang menghemat waktu seperti kemampuan untuk membuat salinan google dokumen secara otomatis bagi setiap Murid. Kelas juga dapat membuat folder drive untuk setiap tugas dan setiap Murid, agar semuanya tetap teratur. Berikut ini tampilan awal google classroom.

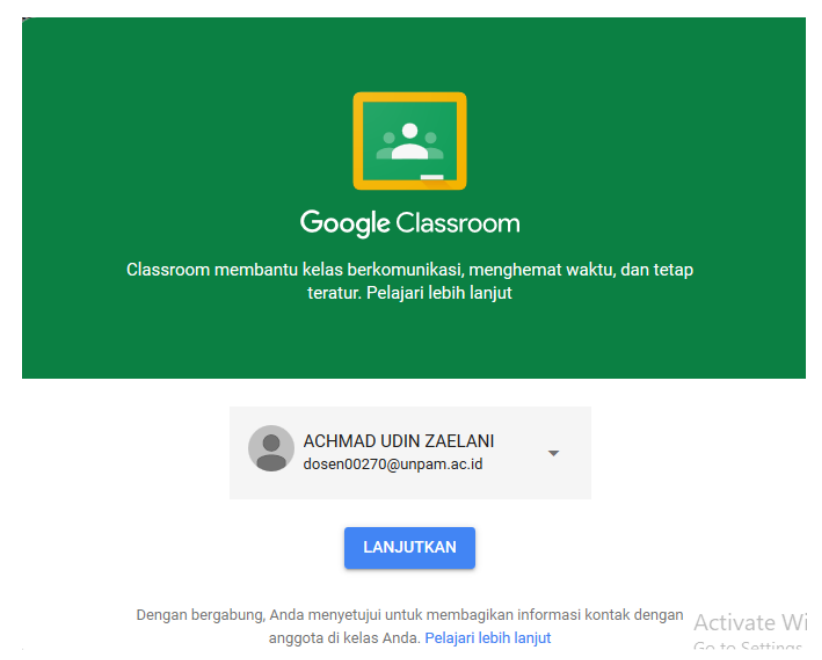

Gambar.1 Tampilan Awal Google Classroom

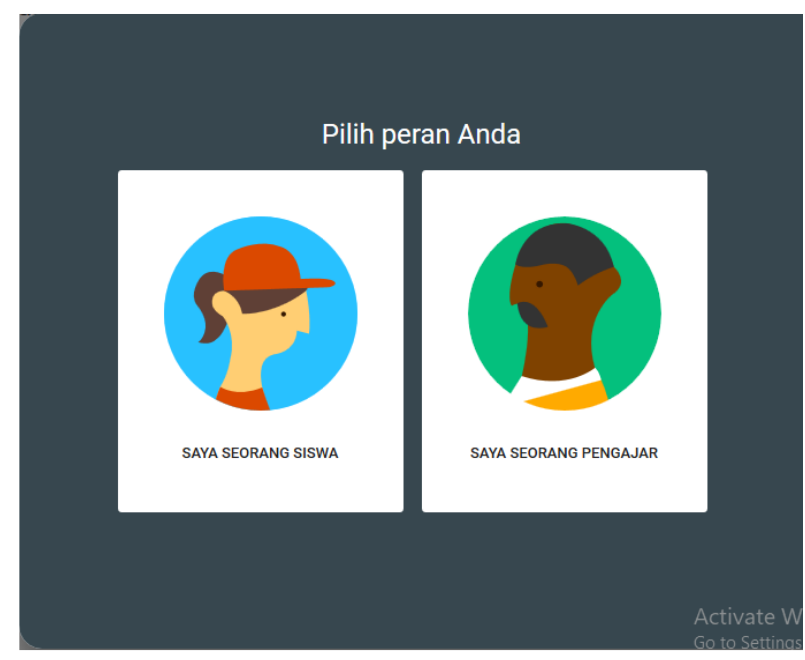

Gambar.2 Pilihan peran di Google Classroom ( Student atau Teacher )

\section{METODE}

\section{Kerangka Pemecahan Masalah}

Memberikan sosialisasi tentang Google Classroom kepada para siswa dan guru dengan memberikan pelatihan dan workshop online tentang Google Classroom dalam 3 hari berturut turut. Mulai dari penyiapan Team Mahasiswa yang membantu dalam 
kegiatan tersebut dan kegiatan workshop online yang diikuti oleh para siswa dan guru SMPIT AL-Mustofa dengan narasumber berasal dari Dosen pembimbing pengabdian kepada Masyarakat dari prodi Teknik Informatika Universitas Pamulang.

\section{Realisasi Pemecahan Masalah}

Adapun langkah-langkah yang kami persiapkan dalam pengabdian masyarakat di SMP Al Mustofa sebagai berikut:

a. Menyiapkan Team Mahasiswa untuk mempersiapkan diri untuk transfer knowledge. Sehingga diperlukan persiapan team yang matang sebelum memberikan pelatihan kepada siswa SMPIT Al Mustofa, Memberikan peluang ke mahasiswa untuk bisa mentransfer knowledge tentang media Google Classroom ke siswa. Sedangkan untuk untuk pelatihan ke guru dilakukan oleh dosen pembimbing langsung via online dan interaktif dengan lewat wokshop online.

b. Memberikan pengenalan dan pelatihan online kepada siswa dan guru tentang Google Classroom sebagai media alternative dalam menghadapi pandemic covid 19 untuk kegiatan Belajar Mengajar.

c. Membuat forum tanya jawab seputar google classroom. Diharapkan dengan langkah-langkah tersebut para siswa didik dan dewan guru yang mengalami kesulitan bisa bertanya dan mendapat solusi tentang permasalahan yang dihadapi tentang pembelajaran via online.

\section{Sasaran Khayalak Program}

Sasaran program pengabdian masyarakat ini ditujukan kepada siswa dan dewan guru SMPIT AL-MUSTOFA di JL. MH. Thamrin, Panukangan Utara Kec. Pinang, Kota Tangerang, Banten. Sejumlah 60 Orang Siswa dan 20 guru. Dengan Outcome yang diharapkan adalah para peserta mengetahui dan memahami tentang penggunaan Google Classroom sebagai media pembelajaran online dan dapat memanfaatkannya semaksimal mungkin. Peserta dapat pengetahuan dan dapat menggunakan aplikasi Google Classroom setelah mengikuti kegiatan PKM yang dilaksanakan. Dan Output dari pengabdian pada masyarakat ini adalah pengetahuan peserta dalam menggunakan Google Classroom sebagai sarana pembelajaran online akibat pandemic covid 19. 


\section{Tempat dan Waktu}

SMPIT AL-MUSTOFA di JL. MH. Thamrin, Panukangan Utara Kec. Pinang, Kota Tangerang, Banten, 17 - 19 Juni 2020.

\section{Metode Kegiatan}

Praktek Online dan Praktek langsung di Lab Sekolah dengan tahapan sebagai berikut:

a. Hari Pertama, diadakan pemaparan materi bagi siswa tentang Google Classroom. Pemaparan ini membahas tentang pengetahuan Google Classroom. Selain pemaparan materi Universitas Pamulang, sesi tanya jawab juga dilakukan untuk memastikan materi yang disampaikan sudah diterima oleh peserta dengan baik.

b. Hari Kedua, pengabdian masyarakat memberikan materi cara menggunakan Google Classroom mulai dari cara membuat kelas, ikut kelas, membuat materi dan submit jawaban dan lain - lain baik dari sebagai murid atau sebagai guru . Lalu dilakukan juga kegiatan praktek guna mengaplikasikan apa yang telah disampaikan sebelumnya, Dari hasil pelatihan di hari kedua, disimpulkan bahwa peserta cukup antusias.

c. Hari ketiga, pengabdian masyarakat memberikan pelatihan tentang Google Classroom dengan mengadakan workshop online, Karena kondisi kegiatan belajar terganggu akibat pandemic covid 19. Sehingga pelatihan terpaksa dilaksanakan dengan online, tetapi antusias dan keberlangsungan pelatihan serta praktek berjalan dengan baik.

\section{HASIL DAN PEMBAHASAN}

\section{Persiapan}

Tindakan dalam tahapan persiapan adalah berupa implementasi program sebagai berikut. Tahap persiapan dilakukan untuk menggali masalah yang berkaitan dengan potensi pembelajaran e-learning. Khusus penggunaan media online Google Classroom. Hasil observasi diperoleh data bahwa fasilitas untuk pembelajaran e-learning di SMPIT AL Mustofa sudah cukup memadai. 
Fasilitas yang ada berupa fasilitas hotspot, LCD di ruang kelas dan juga setiap Murid memiliki smartphone untuk bisa mengakses internet. Namun, fasilitas yang ada tersebut belum bisa dimanfaatkan secara maksimal dikarenakan Murid di SMPIT AL Mustofa belum memaksimalkan softskill dalam menggunakan e-learning, khusus nya Google Classroom. Oleh karena itu, kegiatan pelatihan penggunaan Google Classroom ini sangat penting dan akurat untuk untuk Murid di SMPIT AL Mustofa agar pembelajaran lebih optimal sehingga visi dan misi SMPIT AL Mustofa khusus nya terkait bidang belajar mengajar dapat tercapai dengan baik. Diharapkan setelah dilakukan kegiatan PKM para guru dan siswa termotivasi untuk dapat melakukan pembelajran online dengan media Google Classroom yang telah dipraktekan lewat informasi yang mereka bisa dapat dari internet, pelatihan dan lainnya. Karena pembelajaran online bisa didapat dengan melakukan tahapan-tahapan diatas dengan berani untuk mencoba dan belajar terus menerus.

Bagi pihak sekolah harus terus memberikan kesempatan kepada pihak eksternal terutama dibidang teknologi kekinian untuk mampu menyerap kedalam knowledge anak didiknya bisa dengan melakukan terobosan-terobasan yang efektif. Sehingga siswa mendapatkan pengalaman dan motivasi yang terbaik untuk awal tentang metode online learning lainnya sehingga kegiatan belajar mengajar tidak harus dilakukan diruang kelas saja. Tentu hal tersebut diperlukan investasi yang besar untuk itu perlu menyiapkan infrastruktur yang mendukung dan membuat kegiatan Ekstrakulikuler untuk pembelajaran online learning yag sesuai dengan standar siswa didik.

Dengan menerapkan standar global pada lini lokal yang mampu membuat peserta didik untuk mau belajar. Berdasarkan hal tersebut di atas, tim pengusul bermaksud memberikan pelatihan Google Classroom sebagai media pembelajran online akibat pandemi Covid-19 untuk mampu melaksanakan kegiatan belajar mengajar secara daring. Adapun rincian solusi yang ditawarkan tim pengusul tertuang pada tabel 1 berikut:

Tabel 1. Tahapan Solusi yang Ditawarkan

\begin{tabular}{ll}
\hline Nama Tahapan & \multicolumn{3}{c}{ Solusi yang Ditawarkan } \\
\hline Persiapan & Observasi di lapangan, Merumuskan \\
& permasalahan-permasalahan yang dihadapi oleh \\
& mahasiswa dalam mengoptimalkan potensi \\
& pembelajaran online melalui media Google \\
& Classroom, Menyiapkan materi pelatihan, alat-alat \\
& dan bahan-bahan yang diperlukan untuk kegiatan \\
& pelatihan \\
\hline
\end{tabular}




\begin{tabular}{lll}
\hline Nama Tahapan & \multicolumn{3}{c}{ Solusi yang Ditawarkan } \\
\hline Jenis Pelatihan & $\begin{array}{l}\text { Pelatihan menggunakan dan mengelola Google } \\
\text { Classroom }\end{array}$ \\
\hline $\begin{array}{l}\text { Penentuan Lokasi } \\
\text { Pelatihan }\end{array}$ & Laboratorium SMPIT Al Mustofa & \\
\hline Jumlah Peserta & 60 peserta + 20 Guru & \\
\hline Lama Pelatihan & 3 hari & \\
\hline Monitoring & $\begin{array}{l}\text { Pendampingan dalam menggunakan dan } \\
\text { mengelola Google Classroom }\end{array}$ & \\
\hline Evaluasi & $\begin{array}{l}\text { Jumlah keberhasilan peserta pelatihan } \\
\text { menggunakan dan mengelola Google Classroom }\end{array}$ \\
\hline
\end{tabular}

Adapun rencana pemaparan materi pelatihan menggunakan dan mengelola Google Classroom sebagai media pembelajaran online pada tabel 2 dibawah ini :

Tabel 2. Rencana Pemaparan Materi Pelatihan

\begin{tabular}{ccl}
\hline Hari & Waktu & \multicolumn{1}{c}{ Solusi yang Ditawarkan } \\
\hline Pertama & 120 Menit & Pengenalan Google Classroom \\
\hline Kedua & 120 Menit & $\begin{array}{l}\text { Memanfaatkan berbagai fitur yang terdapat pada Google Classroom } \\
\text { seperti assignments, grading, communication, time-cost, archive } \\
\text { course, mobile application, dan privacy }\end{array}$ \\
\hline Ketiga & 120 Menit & Manajemen kategori dan menu pada Google Classroom \\
\hline
\end{tabular}

\section{Pelaksanaan}

Tahap kedua dalam kegiatan pengabdian ini adalah tahap pelaksanaan. Pada tahap ini dilakukan penyampaian materi e-learning dan pelatihan cara mengakses dan menggunakaan Google Classroom. Tujuan kegiatan penyampaian materi e-learning adalah untuk membekali pengetahuan dan motivasi kepada Murid betapa pentingnya pembelajaran online akibat pandemic covid 19. Sedangkan tujuan kegiatan pelatihan dan cara mengakses dan menggunakaan Google Classroom adalah untuk meningkatkan pengetahuan dan keterampilan para murid dan guru dalam menggunakan Google Classroom sebagai media pembelajaran online. Selain itu, murid juga dapat lebih memahami penggunaan media Google Classroom karena pada kegiatan pelaksanaan ini dilakukan demontrasi penggunaan Google Classroom sebagai media pembelajaran yang telah dibuat dari hasil pelatihan. 

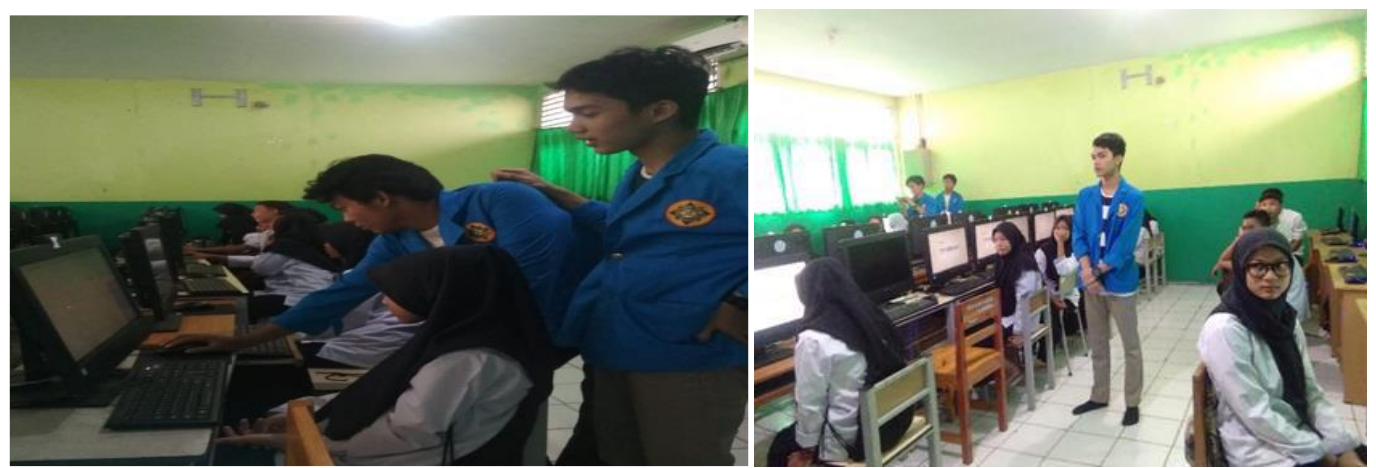

Gambar.3 Pelaksanaan Sosialisasi Hari Pertama

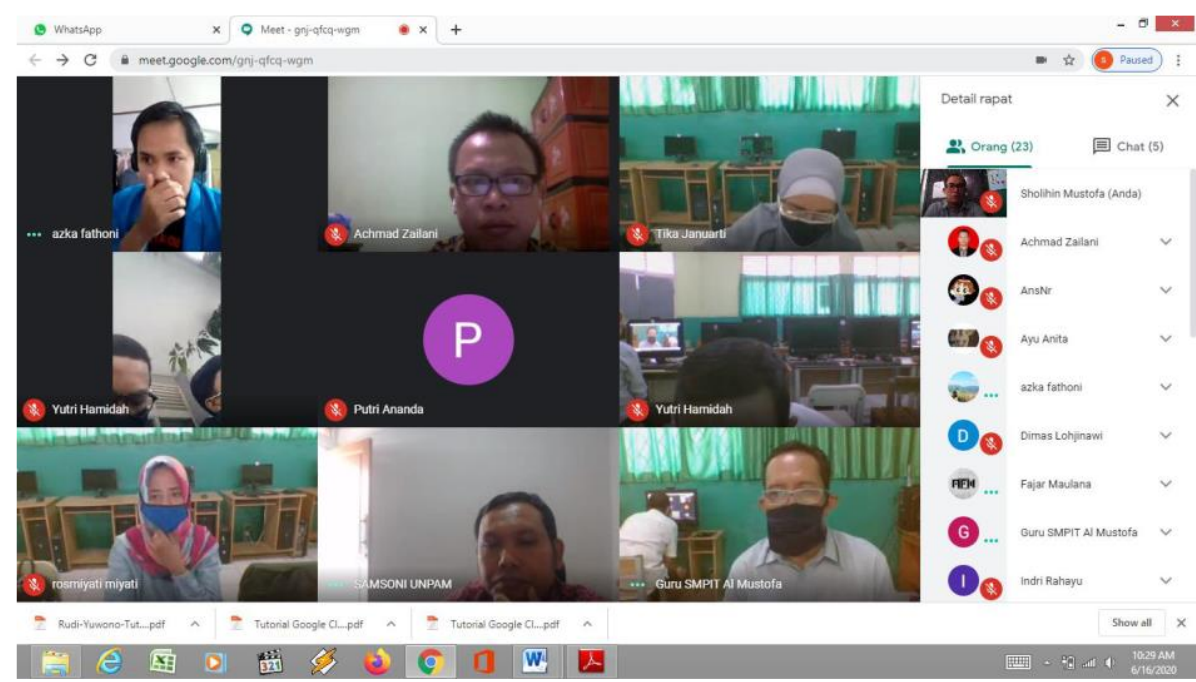

Gambar.4 Pelaksanaan Workshop Online tentang Google Classroom

Pelaksanaan proses pembelajaran dengan memanfaatkan penggabungan komputer dengan teknologi dalam bidang telekomunikasi (internet) telah menjadikan manusia ke era informasi yang maju. Teknologi informasi dan komunikasi (TIK) ini telah banyak memberikan kontribusi dalam proses pembelajaran di dunia pendidikan tinggi. Pengguna TIK sendiri sangat menyebar luas mulai dari kalangan dewasa, remaja, bahkan anak-anak. Pada kegiatan pelatihan proses pembelajaran bagi Guru ini dilakukan dengan memanfaatkan teknologi sebagai metoda pembelajaran e-learning khususnya dengan aplikasi Google. Melalui e-learning siswa dituntut lebih aktif dalam menerima materi kuliah. Penggunaan e-learning lebih efisien karena tidak menuntut waktu dan tempat (Ghulam, Ariyadi, \& Astuti, 2018) 107 Google Classroom mengikat Google Drive, Google Document, Spreadsheet, dan Slide, dan Gmail bersama-sama untuk membantu institusi pendidikan. Google Calendar kemudian diintegrasikan untuk membantu penetapan tanggal jatuh tempo, kunjungan lapangan, dan pembicara kelas. Google 
Calendar juga dapat membantu dalam memberikan penugasan kepada Murid dengan lebih baik yang bisa direncanakan secara teratur.

Kegiatan pelatihan dilakukan dengan diawali pemaparan visi yang disampaikan oleh kepala sekolah. Materi yang disampaikan mengenai pentingnya proses pembelajaran online. Sebelum masuk ketahap pelatihan, pembicara memberikan materi mengenai sosialisasi program Google Classroom. Sosialisasi program dilakukan untuk mengenalkan program dan cara penggunaan kepada guru SMPIT Al Mustofa. Dalam tahapan ini juga disepakati tentang komitmen untuk berpartisipasi untuk melakukan pembelajaran secara penuh waktu selama satu semester salah satunya melalui media Classroom. Kegiatan selanjutnya dilakukan pelatihan penggunaan Classroom sebagai media pembelajaran bagi guru. Pelatihan yang dilakukan meliputi pembuatan akun Google Classroom, cara membuka kelas dan membuat kode kelas, menambahkan materi matapelajaran, membuat daftar presensi kehadiran untuk siswa, membuat quiz atau tugas serta cara penilaian. Pada pelatihan juga diajarkan untuk membuat kelas kolaborasi, dimana dalam satu kelas pada satu mata pelajaran bisa diisi oleh lebih dari satu guru. Guru yang memiliki kemampuan di bidang yang sama bisa ikut andil memberikan materi kepada kelas lain. Tampilan Google Classroom yang diajarkan. Tahapan pelatihan dilaksanaakn dengan tujuan untuk memberikan kesempatan bagi guru untuk langsung mempraktikan apa yang telah diajarkan oleh pembicara. guru mencoba membuat membuka kelas dan menambahkan materi ajar, serta membuat kuis atau tugas. Kegiatan selanjutnya dilakukan pelatihan penggunaan Classroom sebagai media pembelajaran bagi siswa. Pelatihan yang dilakukan meliputi pembuatan akun Google Classroom, cara ikut kelas dan menjawab tugas, mengupload tugas. Pada pelatihan juga diajarkan untuk mengikuti kelas kolaborasi, dimana dalam satu kelas pada satu mata pelajaran bisa diisi oleh lebih dari satu siswa. Selanjutnya guru dan siswa mempraktekan apa yang sudah dilakukan selama pelatihan yang dilakuakan tujuan untuk memberikan kesempatan bagi guru dan siswa untuk langsung mempraktikan apa yang telah diajarkan oleh pembicara. guru mencoba membuat membuka kelas dan menambahkan materi ajar, serta membuat kuis atau tugas dan siswa menjawabnya.

\section{Evaluasi}


Tahap ketiga dalam kegiatan pengabdian ini adalah tahap evaluasi. Pada tahap ini dilakukan Evaluasi untuk mengetahui kendala selama pelatihan. Kegiatan pengabdian yang dilaksanakan bagi murid dan guru di SMPIT AL Mustofa telah berlangsung dengan baik. Hal ini terlihat dari sambutan positif dan antusiasme dari murid dan guru untuk mengikuti pelatihan dengan baik.

\section{SIMPULAN DAN SARAN}

\section{Simpulan}

Berdasarkan hasil Pengabdian Kepada Masyarakat yang telah dilakukan, didapatkan:

a. Hasil yang dicapai bahwa bertambahnya pengetahuan murid dan guru di SMPIT AL Mustofa tentang pembelajaran e-learning dan terampil dalam menggunakan Google Classroom sebagai media pembelajaran online yang interaktif dan menyenangkan dalam proses kegiatan belajar mengajar terutama ketika masa pandemic covid 19.

b. Adanya produk e-learning yaitu Google Classroom sebagai media pembelajaran online yang mudah digunakan.

\section{Saran}

a. Perlu dibuat community Google Classroom dikalangan siswa dengan adanya pembimbing bisa dari guru atau pihak eksternal yang mumpuni di bidangnya.

b. Kegiatan pelatihan sejenis bisa dilakukan per semester.

\section{DAFTAR PUSTAKA}

Ghulam, A. B., Ariyadi, D., \& Astuti, I. P. (2018). Pemanfaatan E-learning Queffer School oleh Guru dan Siswa untuk Optimalisasi Pembelajaran di MAN 1 Ponorogo. Jurnal Pengabdian Kepada Masyarakat, 3(2), 153-160.

Hakim, A.B. (2016). Efektifitas Penggunaan E-Learning Moodle, Google Classroom Dan Edmodo. I-STATEMENT: Information System and Technology Management, 2(1), 1-6.

Sabran, \& Sabara, E. (2019). Keefektifan Google Classroom sebagai media pembelajaran. PROSIDING SEMINAR NASIONAL LEMBAGA PENELITIAN UNIVERSITAS NEGERI MAKASSAR "Diseminasi Hasil Penelitian melalui 
Optimalisasi Sinta dan Hak Kekayaan Intelektual”, 122-125. Makasar: Universitas Negeri Makassar.

Soni, Hafid, A., Hayami, R., Fatma, Y., Wenando, F. A., Al Amien, J., . . Hasanuddin. (2018). Optimalisasi Pemanfaatan Google Classroom sebagai Media Pembelajaran di SMK Negeri 1 Bangkinang. Jurnal Pengabdian Untuk $M u$ NegeRI, 2(1), 17-20.

Zailani, A. U., Perdananto, A., Nurjaya, \& Sholihin. (2020). Pengenalan Sejak Dini Siswa SMP tentang Machine Learning untuk Klasifikasi Gambar dalam Menghadapi Revolusi 4.0. KOMMAS: Jurnal Pengabdian Kepada Masyarakat, 1(1), 7-15. 